\title{
The neurobiology of mouse models syntenic to human chromosome 15q
}

\author{
Toru Takumi
}

Received: 1 December 2010 / Accepted: 12 July 2011 / Published online: 26 July 2011

(C) Springer Science+Business Media, LLC 2011

\begin{abstract}
Autism is a neurodevelopmental disorder that manifests in childhood as social behavioral abnormalities, such as abnormal social interaction, impaired communication, and restricted interest or behavior. Of the known causes of autism, duplication of human chromosome 15q11-q13 is the most frequently associated cytogenetic abnormality. Chromosome $15 q 11-q 13$ is also known to include imprinting genes. In terms of neuroscience, it contains interesting genes such as Necdin, Ube3a, and a cluster of $\mathrm{GABA}_{\mathrm{A}}$ subunits as well as huge clusters of non-coding RNAs (small nucleolar RNAs, snoRNAs). Phenotypic analyses of mice genetically or chromosomally engineered for each gene or their clusters on a region of mouse chromosome seven syntenic to human $15 q 11-q 13$ indicate that this region may be involved in social behavior, serotonin metabolism, and weight control. Further studies using these models will provide important clues to the pathophysiology of autism. This review overviews phenotypes of mouse models of genes in 15q11-q13 and their relationships to autism.
\end{abstract}

Keywords $15 q 11-q 13 \cdot$ Mouse model $\cdot$ Autism . Chromosome $\cdot$ CNV $\cdot$ Serotonin $\cdot$ Epigenetics

T. Takumi $(\bowtie)$

Laboratory of Integrative Bioscience,

Graduate School of Biomedical Sciences, Hiroshima University,

1-2-3 Kasumi, Minami,

Hiroshima 734-8553, Japan

e-mail: takumi@hiroshima-u.ac.jp

T. Takumi

Japan Science and Technology Agency (JST), CREST, Chiyoda,

Tokyo 102-0075, Japan

\section{Autism}

Autism is a developmental brain disorder whose definition has been extended to autism spectrum disorders (ASDs), including non-pervasive development disorder and Asperger syndrome (Levitt and Campbell 2009). The prevalence of autism is increasing and currently stands at one in every 150 individuals. Its influence on modern society is increasing, especially in developed countries, where birthrates are low and the management of children with these disorders is a serious social issue. However, the cause of autism and its pathophysiology remain unknown and require further research from a number of different approaches. Among the neuropsychiatric diseases, autism is considered as an appropriate disorder that can be approached from biological aspects. This is partly because genetic studies show that the concordance rate of autism in identical twins is over $90 \%$, which is higher than other neuropsychiatric diseases such as schizophrenia and mood disorders (Abrahams and Geschwind 2008).

Most autism cases are sporadic and their causes are still unknown; however, 10-20\% have known causes, such as (1) comorbidity with other diseases, such as fragile $\mathrm{X}$ syndrome, tuberous sclerosis, and Rett syndrome; (2) genome abnormalities, including copy number variations (CNVs), such as 15q11-q13 and 16q11.2; and (3) single gene mutations such as $N L G N 3 / 4, N R X N 1$, and $S H A N K 2 / 3$ (Abrahams and Geschwind 2008; Berkel et al. 2010; Cook and Scherer 2008; Kumar et al. 2008; Marshall et al. 2008; Pinto et al. 2010; Toro et al. 2010; Vorstman et al. 2006; Weiss et al. 2008). Recent genetic screening using cuttingedge technologies has revealed more CNV cases than previously expected (Cook and Scherer 2008). Given the 
rapid progress in current technologies, such as array comparative genomic hybridization (array $\mathrm{CGH}$ ) and next generation sequencers, and their availability for clinical use, it is likely that more $\mathrm{CNV}$ cases will be diagnosed in the near future.

CNVs are important not only in explaining human heterogeneity but also because they are responsible for several diseases, especially neuropsychiatric disorders including autism. Human chromosome $15 \mathrm{q} 11-\mathrm{q} 13$ is the second most frequent region to contain chromosome abnormalities, probably because it contains large repeat sequences. Depending on its copy variant, this region causes different diseases, such as Prader-Willi syndrome (PWS), Angelmann syndrome (AS), and autism, all sharing ASD features. Comparison of mouse models of $15 q$ copy variants with phenotypes of genetically engineered mice of each gene, with or without imprinting, will provide some clues to the pathophysiology of autism.

\section{Mouse chromosome seven is syntenic to human chromosome 15q11-q13}

Chromosomal abnormalities were known as causes of autism before the era of current genome technology. Among them, human $15 \mathrm{q} 11-\mathrm{q} 13$ is the most notable chromosome region (Vorstman et al. 2006) (Fig. 1). This region is also known to be an imprinting region (Chamberlain and Lalande 2010a, b; Nicholls and Knepper 2001). Thus, there are three classified regions: paternally, maternally, and biallelically expressed regions. Human chromosome $15 \mathrm{q} 11-\mathrm{q} 13$ is conserved in mouse chromosome seven and it is believed that the imprinting status is conserved between mouse and human (Yang et al. 1998). Knockout (KO) mice for each gene corresponding to a human counterpart have been generated and studied (Table 1).

\section{Paternally expressed genes}

In the paternally expressed regions of the mouse chromosome, Mkrn3, Magel2, Necdin (Ndn), Snrpn-Snurf, and huge clusters of small nucleolar RNAs (snoRNAs) are present. Magel2 is involved in hypothalamic functions, and its deficient mice show abnormal circadian rhythm, body weight, and hormonal secretion, such as testosterone (Bischof et al. 2007; Kozlov et al. 2007; Mercer and Wevrick 2009). Ndn was first identified as a gene related to neural differentiation (Maruyama et al. 1991). Ndn KO mice were generated from multiple laboratories; however, they display different phenotypes, from no abnormality to respiratory distress and lethality, similar to PWS, depending on the strain of mouse (Gerard et al. 1999; Kuwako et al. 2005; Muscatelli et al. 2000; Tsai et al. 1999a). Muscatelli et al. observed a neonatal lethality of variable penetrance in $N d n$ mutants, and they showed a reduction in both oxytocin-producing and luteinizing hormone-releasing hormone (LHRH)-producing neurons in the hypothalamus and emotional and cognitive-related behaviors reminiscent of PWS (Muscatelli et al. 2000). Interestingly, oxytocin is known to be related to social behavior and is expected to be a candidate for therapeutics of ASD (Insel 2010). $N d n$ deficiency induces perinatal serotonergic alterations that affect the maturation and function of the respiratory network, inducing respiratory problems (Zanella et al. 2008). Serotonergic and catecholaminergic projections are reduced in the Ndn null embryo (Lee et al. 2005). Provided that serotonin is involved in symptoms of autism, $N d n$ is a candidate for further studies to reveal its involvement in abnormal social behavior. Additionally, from studies using $N d n \mathrm{KO}$ mice, it is reported that $N d n$ is involved not only in TrkA signaling (Kuwako et al. 2005) but also promotes tangential migration of neocortical interneurons from the basal forebrain (Kuwajima et al. 2010). The fact that the neocortical interneurons are important for development of inhibitory neural circuits also makes $N d n$ a possible candidate for causing an imbalance of the excitatory/ inhibitory ratio. Thus, although it is still controversial whether $N d n$ is a cause of PWS, it is an intriguing target gene for further analyses in terms of developmental brain disorders, including ASDs. Snrpn is a small nuclear ribonucleoprotein N and the Snrpn promoter is located in a maternally methylated $\mathrm{CpG}$ island within an imprinting center (IC). Mutations of Snrpn are not sufficient to induce PWS in mice, but a larger deletion including the PWS-IC and Ndn show phenotypes common to PWS infants (Yang et al. 1998). Paternal transmission of IC deletions results in a PWS-like phenotype in mice (Bielinska et al. 2000). The

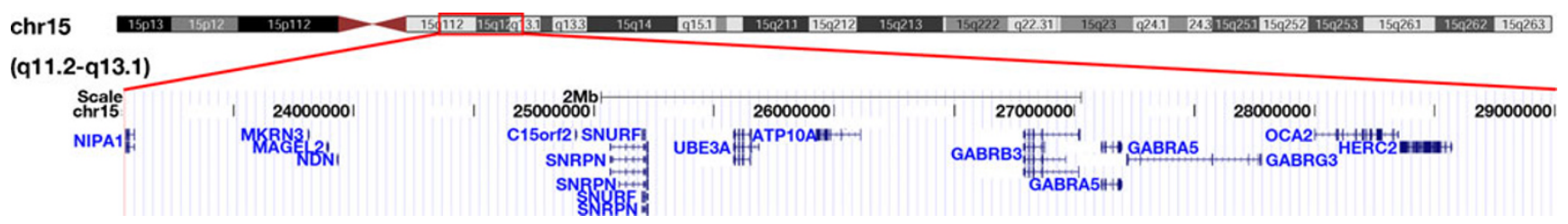

Fig. 1 Genes on human chromosome 15q11-q13. Clusters of non-coding RNA, such as HBII-52 and HBII-85, are omitted. The original data are taken from UCSC Genome Browser (http://genome.ucsc.edu) 
Table 1 Genes on human chromosome 15q11-q13 and the phenotypes of their genetically engineered mice

\begin{tabular}{|c|c|}
\hline Locus & Line \\
\hline Mkrn3 & $\mathrm{KO}$ \\
\hline \multirow[t]{3}{*}{ Magel2 } & $\begin{array}{l}\text { Targeted reporter } \\
\text { (LacZ insertion) } \\
\text { Targeted reporter } \\
\text { (LacZ insertion) }\end{array}$ \\
\hline & $\begin{array}{l}\text { Targeted reporter } \\
\text { (LacZ insertion) }\end{array}$ \\
\hline & Conventional KO \\
\hline \multirow[t]{5}{*}{ Ndn } & Conventional $\mathrm{KO}$ \\
\hline & $\begin{array}{l}\text { Targeted reporter } \\
\text { (LacZ insertion) } \\
\text { Conventional KO }\end{array}$ \\
\hline & Conventional $\mathrm{KO}$ \\
\hline & Conventional KO \\
\hline & Conventional $\mathrm{KO}$ \\
\hline \multirow[t]{3}{*}{ PWS-IC } & Conventional $\mathrm{KO}$ \\
\hline & Conventional $\mathrm{KO}$ \\
\hline & $\begin{array}{l}\text { Gene targeting } \\
\text { (SNRPN human exon } 1 \text { switch) }\end{array}$ \\
\hline Snurf & Conventional $\mathrm{KO}$ \\
\hline \multirow[t]{3}{*}{ Snrpn } & Conventional $\mathrm{KO}$ \\
\hline & Conventional $\mathrm{KO}(\mathrm{Ex} 1=0.9 \mathrm{~kb})$ \\
\hline & $\begin{array}{l}\text { Conventional KO } \\
\left(\text { Ex1=4.8 kb) PWS-IC }{ }^{+/-}\right.\end{array}$ \\
\hline \multirow[t]{2}{*}{$\begin{array}{l}\text { MBII-85/ } \\
\text { Snord116 }\end{array}$} & $\begin{array}{l}\text { Chromosome engineering } \\
\text { (Cre lox deletion) }\end{array}$ \\
\hline & $\begin{array}{l}\text { Chromosome engineering } \\
\text { (Cre lox deletion) }\end{array}$ \\
\hline $\begin{array}{l}\text { MBII-52/ } \\
\text { Snord115 }\end{array}$ & $\begin{array}{l}\text { Radiation induced mutant } \\
\text { (large deletion) } \mathrm{p}^{30 \mathrm{pUb}} \\
\text { Conventional KO } \\
(\mathrm{Ex} 1=4.8 \mathrm{~kb}) \mathrm{PWS}^{-\mathrm{IC}^{+/-}}\end{array}$ \\
\hline $\begin{array}{l}\text { Snurf-Snrpn to } \\
\text { Ube3a deletion }\end{array}$ & $\begin{array}{l}\text { Chromosome engineering } \\
\text { (Cre-loxP deletion) }\end{array}$ \\
\hline Ube3a & $\begin{array}{l}\text { Conventional KO } \\
\text { (maternal transmission) }\end{array}$ \\
\hline
\end{tabular}
and luteinizing hormone releasing hormone producing neuron, skin scraping, increased spatial learning

Reduced substance P containing neuron, high tolerance to thermal pain

Central respiratory deficits, altered serotonergic metabolism, enlargement of 5-HT vesicles

Impaired tangential migration of cortical interneuron

Died shortly after birth, small

Imprinting defect

Paternal transmission postnatal lethality (not fully penetrant), growth deficiency. Loss of Ndn, Magel2, and Mkrn3 expression No obvious phenotype

No obvious phenotype

No obvious phenotype

40-50\% lethality (strain dependency)

Early onset postnatal growth deficiency, defect of motor learning, increased anxiety, hyperphagia

Postnatal lethality (strain dependency), growth retardation

Paternal transmission: loss of MbII-52/Snord115 and Ube 3 a expression. No obvious phenotype Increased in editing of $5 \mathrm{htr} 2 \mathrm{c}$, impulsive responding, less locomotor activity, reactivity to palatable foodstuffs

Partial postnatal lethality, growth deficiency

Maternal transmission: reduced brain weight, impaired motor function, inducible seizures, deficit in context-dependent fear conditioning, abnormal hippocampal electroencephalographic recordings and severely impaired long-term potentiation

Targeted reporter (maternal transmission LacZ insertion)

Targeted reporter (maternal transmission LacZ insertion)

paternal transmission: reduced brain weight impaired motor function, impaired spatial learning, deficit in context-dependent fear conditioning, abnormal hippocampal electroencephalographic recordings

Sleep disturbance
Reference

Jong et al. 1999

Bischof et al. 2007

Kozlov et al. 2007

Mercer and Wevrick 2009

Schaller et al. 2010

Gerard et al. 1999

Tsai et al. 1999a

Muscatelli et al. 2000

Kuwako et al. 2005

Zanella et al. 2008

Kuwajima et al. 2010

Yang et al. 1998

Bielinska et al. 2000

Johnstone et al. 2006

Tsai et al. 1999b

Yang et al. 1998

Bressler et al. 2001

Bressler et al. 2001

Ding et al. 2008

Skryabin et al. 2007

Ding et al. 2005

Doe et al. 2009

Tsai et al. 1999b

Jiang et al. 1998

Miura et al. 2002 
Table 1 (continued)

\begin{tabular}{|c|c|}
\hline Locus & Line \\
\hline & $\begin{array}{l}\text { Conventional KO } \\
\text { (maternal transmission)/ } \\
\text { CamKII-T305V/T306A } \\
\text { double mutant } \\
\text { YFP fused to Ube3a }\end{array}$ \\
\hline & $\begin{array}{l}\text { Conventional KO } \\
\text { (maternal transmission) }\end{array}$ \\
\hline & $\begin{array}{l}\text { Conventional KO } \\
\text { (maternal transmission) }\end{array}$ \\
\hline & $\begin{array}{l}\text { Conventional KO } \\
\text { (maternal transmission) }\end{array}$ \\
\hline Atp10a & $\begin{array}{l}\text { Radiation induced } \\
\text { chromosomal deletion } \mathrm{p}^{30 \mathrm{PUb}} \\
\text { (Ube3a to Gabrb3 deletion) }\end{array}$ \\
\hline Ube3a-Gabrb3 & $\begin{array}{l}\text { 1.6 } \mathrm{Mb} \text { deletion (Ube3a to Gabrb3) } \\
\text { chromosome engineering }\end{array}$ \\
\hline Gabrb3 & Conventional KO mouse \\
\hline
\end{tabular}

Conventional KO mouse

Conventional $\mathrm{KO}$ mouse

Conventional $\mathrm{KO}$ mouse

Point mutation KI mouse (N265M; second

transmembrane region)

Conventional $\mathrm{KO}$ mouse

Conventional $\mathrm{KO}$ mouse

Conditional KO

(CamKII or Synapsin I Cre)

Gabra5 Conventional KO mouse

Conventional $\mathrm{KO}$ mouse

Conventional $\mathrm{KO}$ mouse

Point mutation KI mouse (H105R; diazepam insensitive)

Point mutation KI mouse (H105R)

Gabrg3 No

Oca2 Spontaneous, ENU induced, radiation induced mutant mouse

Herc2 Spontaneous, ENU induced, radiation induced mutant mouse (many mutants)
Phenotypes

Reference

Rescued various abnormalities in

van Woerden et al. 2007

Ube3a-/+ mutant; reduced seizure, improved motor coordination and spatial learning

Visualized ube3a protein, Ube3a is imprinted in all regions of the brain

Altered licking behavior, defects in rope

climbing, grip strength, gait, and a raised beam task

Impaired experience dependent maturation of excitatory cortical circuits, deficits in ocular dominance plasticity

Lack of rapid and mature ocular dominance plasticity

Maternal deletion showed greater body weight, adiposity index, plasma insulin, leptin, triglyceride concentration

Similar to the phenotypes of Ube3a and Gabrb3

$\mathrm{KO}$ mice, increased USVs

$90 \% \mathrm{KO}$ mice display neonate $(-24 \mathrm{~h})$ lethal, $60 \%$ cleft palate, some mice are viable that showed hyperactive, higher sensitivity to sensory stimuli, motor difficulties, myoclonus, epileptic seizures

Electroencephalographic abnormality, seizures, deficits in learning and memory, poor motor skills

$44 \%$ decreased norepinephrine in spinal cord

Lower REM sleep time, greater EEG delta power

Abolished suppression of noxious-evoked movements in response to the intravenous anesthetics

Enlarged pericoerulear dendritic zone of the locus coeruleus, hypotonia, less marble burying behavior

Deficits in activities related to social behavior, altered exploratory behavior, hypoplasia of the cerebellar vermis

Synapsin $\mathrm{I}=>60 \%$ died in neonate, CamKII $=>30 \%$ died in $15-25$ days of age, hyperactive, sensitive for etomidate

Enhanced spatial learning, decreased amplitude of IPSC, and enhanced amplitude of paired-pulse facilitation of fEPSP in CA1 of hippocampus

Normal behavioral phenotype for fear-associated contextual learning Reduced threshold for the induction of LTP Impaired the activity of diazepam, reduction of Gabra5 protein level, facilitated trace fear conditioning

Attenuated prepulse inhibition, increased spontaneous locomotor activity

No

Hypopigmentation, melanosomal defect

Sterility, defects in growth, coordination, fertility, maternal behavior. Jerky gait
Dindot et al. 2008

Heck et al. 2008

Yashiro et al. 2009

Sato and Stryker 2010

Dhar et al. 2004

Jiang et al. 2010

Homanics et al. 1997

DeLorey et al. 1998

Ugarte et al. 2001

Wisor et al. 2002

Jurd et al. 2003

Hashemi et al. 2007

DeLorey et al. 2008

Ferguson et al. 2007

Collinson et al. 2002

Cheng et al. 2006

Martin et al. 2010

Crestani et al. 2002

Hauser et al. 2005

No

Gardner et al. 1992

Johnson et al. 1995

Lehman et al. 1998

Walkowicz et al. 1999 
human PWS-IC could acquire a methylation imprint in mouse oocytes but the imprint is lost in somatic cells, suggesting that the human imprinting center demonstrates conserved acquisition, but diverged maintenance, of imprinting in a mouse model for AS imprinting defects (Johnstone et al. 2006). The main promoter of Snrpn is not required for the function of the PWS-IC, and the 4.8-kb deletion induces a severe phenotypic effect and a partial imprinting defect; however, this defect is less severe than that with the 42-kb deletion of the PWS-IC (Bressler et al. 2001; Yang et al. 1998). Paternal deletion from Snrpn to Ube $3 a$ in the mouse causes hypotonia, growth retardation, and partial lethality (Tsai et al. 1999b). The non-coding RNA region includes HBII-52 and HBII-85. Knockout mice of MBII-85, a mouse homolog of HBII-85, show growth retardation, increased anxiety, and hyperphagia (Ding et al. 2008; Skryabin et al. 2007). Recently, HBII-85 was reported as a cause of PWS (Duker et al. 2010; Sahoo et al. 2008). On the other hand, knockout mice of MBII-52, a mouse homolog of HBII-52, display increased RNA editing of the serotonin $2 \mathrm{c}$ receptor (5-HT2cR) and less locomotor activity (Doe et al. 2009). In terms of the relationship between serotonin and autism, MBII52 is an interesting candidate gene.

\section{Maternally expressed genes}

Maternally expressed genes in chromosome 15q11-q13 include Ube3a and Atp10a. Ube $3 a$ is an E3 ubiqutin ligase and is known to be a causative gene for AS (Kishino et al. 1997; Matsuura et al. 1997). Ube3a knockout mice show impaired motor function, inducible seizures, learning deficits (Jiang et al. 1998; Miura et al. 2002), and sleep disturbance (Colas et al. 2005). The ataxic and long potentiation phenotypes are rescued by reduction of $\alpha$ CaMKII inhibitory phosphorylation (van Woerden et al. 2007). Knock-in (KI) Ube3a-YFP fusion reporter mice show that $U b e 3 a$ is imprinted in all regions of the brain, but is biallelically expressed in glial cells (Dindot et al. 2008). Maternally Ube3a-deficient mice show altered linking behavior, which has been associated with cerebellar control (Heck et al. 2008). Recently, Ube3a was extensively characterized in neurons and found to be involved in synaptic plasticity (Greer et al. 2010; Margolis et al. 2010; Sato and Stryker 2010; Yashiro et al. 2009). A genetic study also reported the involvement of Ube3a in ASD (Glessner et al. 2009). Ube3a is the primary candidate gene for causing the phenotypic features in duplication $15 \mathrm{q}$ autism. In contrast, Atp10a, an aminophospholipid translocase, has been less comprehensively studied than Ube $3 a$, and its imprinting status remains unclear (DuBose et al. 2010; Kayashima et al. 2003). Mice with a radiation-induced maternal deletion, including Ube3a and Gabrb3, are a model of obesity and type two diabetes (Dhar et al. 2004). Mice with a large maternal deletion from Ube3a to Gabrb3, produced by chromosome engineering, show altered ultrasonic vocalization, impaired learning and memory, and display parent of origin effects (Jiang et al. 2010).

\section{Non-imprinting genes}

In the conventional biallelic region, there is a cluster of $\mathrm{GABA}_{\mathrm{A}}$ receptor subunits (Gabrb3, Gabra5, Gabrg3), Oca2, and Herc2. The $\mathrm{GABA}_{\mathrm{A}}$ receptor is one of the major neurotransmitter receptors and forms the most notable target in this region because an imbalance between excitatory and inhibitory neurons during development is a pathophysiological hypothesis of developmental brain disorders, including ASD (Rubenstein and Merzenich 2003). Of the $\mathrm{GABA}_{\mathrm{A}}$ receptor subunits, the $\mathrm{GABA}_{\mathrm{A}} \beta 3$ subunit (encoded by the Gabrb3 gene) is well studied. Its deficient mice show epileptic seizures, deficits in learning and memory, poor motor skills (DeLorey et al. 1998; Homanics et al. 1997), as well as sleep disturbance, such as lower REM sleep time and greater EEG delta power than the wild-type (WT) (Wisor et al. 2002). The level of norepinephrine in the spinal cord of Gabrb3 KO mice was less than that of WT mice, suggesting that $\beta 3$ subunit-containing $\mathrm{GABA}_{\mathrm{A}}$ receptors mediate the trophic effects on a subpopulation of spinally projecting noradrenergic neurons (Ugarte et al. 2001). Furthermore, Gabrb3 N265M KI mice display altered general anesthetic actions (Jurd et al. 2003). Gabrb3 KO mice show expansion of the plexus of locus coeruleus dendrites, with a concurrent reduction in muscle tone and marble burying behavior (Hashemi et al. 2007). They also exhibit hypoplasia of cerebellar vermal lobules and impaired social and exploratory behaviors in addition to deficits in non-selective attention (DeLorey et al. 2008). Survivors of pan-neuronal Gabrb3 knockouts are overtly normal, whereas those of forebrain selective knockouts have reduced fertility, are hyperactive, and some become obese (Ferguson et al. 2007). An association between a specific $\mathrm{GABA}_{\mathrm{A}} \beta 3$ receptor defect and autism has been reported recently (Delahanty et al. 2010). Thus, Gabrb3 is also an intriguing candidate gene in the region with respect to autism. Gabra5 KO mice display enhanced spatial learning, decreased amplitude of inhibitory post-synaptic current (IPSC), and enhanced amplitude of paired-pulse facilitation of excitatory postsynaptic potential (EPSP) (Collinson et al. 2002). While Gabra5 KO mice exhibit a normal behavioral phenotype for fear-associated contextual learning (Cheng et al. 2006) and no differences in long-term potentiation (LTP) in hippocampal slices (Collinson et al. 2002), they show reduced threshold for the induction of LTP via mechanisms that are indepen- 
dent of synaptic inhibition (Martin et al. 2010). On the other hand, $\alpha 5$ (H105R) KI mice, in which a partial reduction of $\alpha 5 \mathrm{GABA}_{\mathrm{A}}$ receptor restricted to CA1-3 subfield of the hippocampus was achieved, exhibit facilitated trace fear conditioning (Crestani et al. 2002). Moreover, H105R mutant mice show attenuated prepulse inhibition (PPI) and increased spontaneous locomotor activity (Hauser et al. 2005). Herc2 contains a $\mathrm{COOH}$-terminal HECT domain and functions as an assembly factor for the complex of an E3 ubiquitin ligase (Bekker-Jensen et al. 2010). Mutant mice of Herc2 show defects in growth (Lehman et al. 1998), but the physiological functions of Herc2 in the brain remain unknown.

\section{Genes between BP1 and BP2}

In addition to genes between breakpoints BP2 and BP3, there are four highly homologous genes (Nipa1, Nipa2, Cyfip1, and Tubgcp5) in between BP1 and BP2 (Chai et al. 2003), which appear to result in developmental behavioral problems when disturbed (Doornbos et al. 2009; Tam et al. 2010; van der Zwaag et al. 2010; von der Lippe et al. 2011). Cyfip1 (cytoplasmic FMRP interacting protein, also known as $\mathrm{Sra}-1$ ) is an intriguing candidate among them because it binds with the Fragile X protein (Schenck et al. 2001). Microarray analysis using lymphoblastoid cells from males with autism due to a $15 \mathrm{q} 11-\mathrm{q} 13$ duplication reveal that Cyfip1 is upregulated (Nishimura et al. 2007). Although there is no mouse model of Cyfipl at this moment, it would be interesting to make both Cyfipl deletion and transgene animals since individuals with $15 \mathrm{q}$ duplications and AS deletion patients have a larger deletion that includes Cyfip 1 (Sahoo et al. 2006).

\section{Genomic diseases in human chromosome 15q11-q13}

In humans, a paternal deletion of 15q11-q13 causes PWS in which the patient shows hypotonia, obesity, cognitive deficit, and behavioral problems, including obsessive-compulsive disorder (Cassidy and Driscoll 2009; Chamberlain and Lalande 2010b). Maternal deletion of this region causes AS, which includes motor dysfunction, frequent seizures, learning disability, absent speech, and characteristic happy demeanor (Van Buggenhout and Fryns 2009). Both PWS and AS share ASD features (Schanen 2006; Sutcliffe and Nurmi 2003). On the other hand, duplication of this region is known to be the most frequent cytogenetic abnormality in ASDs (Hogart et al. 2010; Vorstman et al. 2006). Autism with 15q duplication syndrome was first reported as partial trisomy of chromosome 15 (Gillberg et al. 1991). It is widely believed that maternally duplicated cases cause autism, but paternally duplicated ones do not (Bolton et al. 2001; Browne et al.
1997; Cook et al. 1997; Mao et al. 2000; Repetto et al. 1998; Roberts et al. 2002). On the other hand, cases with developmental delay are documented with paternal duplications (Bolton et al. 2004; Mao et al. 2000; Mohandas et al. 1999; Roberts et al. 2002; Veltman et al. 2005). A recent screening using multiplex ligation-dependent probe amplification (MLPA) did not detect maternal duplication, suggesting that ASD cases in maternal duplication are not as frequent as previously assumed (Depienne et al. 2009). Recent advances in genetic analyses, such as array $\mathrm{CGH}$, and their clinical application are expected to detect larger numbers of clinical cases for $15 \mathrm{q}$ duplication.

\section{A mouse model for $15 q$ duplication}

Using a chromosome-engineering technique (Mills and Bradley 2001; van der Weyden and Bradley 2006; Yu and Bradley 2001), a model for human chromosome $15 q$ duplication has been generated (Nakatani et al. 2009). The duplication was confirmed in ES cells by Southern blotting and in mice by fluorescence in situ hybridization (FISH) and CGH arrays. Southern blot analysis using methylation sensitive and insensitive restriction enzymes, and a probe near the IC, indicated that allele-specific methylation is conserved in mice with the duplication. As the region is imprinted, the duplication is classified into two types: $\mathrm{patDp} /+$ mice, in which the duplicated region is derived from the paternal allele; and matDp/+ mice, in which the duplication is derived from the maternal allele.

Both patDp/+ and matDp/+ mice breed normally and are fertile (Nakatani et al. 2009). The patDp/+ male mice begin to show an increase in body weight after 15 weeks and the body weight of patDp/+ mice is significantly greater than that of the WT after 20 weeks. The fact that both decreased (PWS) and increased (15q duplication) gene expressions of PWS regions lead to obesity is contradictory, but rather intriguing. As described above, Atp10a seems to be involved in metabolism and body weight (Dhar et al. 2004). Further, some of forebrain specific KO mice of Gabrb3 also become obese (Ferguson et al. 2007). The PWS region is involved in aspects of metabolism and above a certain critical threshold, the amounts of the genes and their products, regardless of any increase or decrease, may result in an abnormal pathway of metabolism.

Histological analyses, either at the macroscopic level or at the microscopic level, using simple staining such as hematoxylin-eosin or Bodian staining, detect no significant difference between mice with the duplication and WT mice (Nakatani et al. 2009). Recent studies reveal that synaptic adhesion molecules, and their associated proteins, are known to be rare mutation cases in autism (Betancur et al. 2009; Bourgeron 2009; Toro et al. 2010). For example, 
Shank3 mutant mice display abnormality in spines (Bozdagi et al. 2010; Peca et al. 2011). Thus, it will be quite interesting as to whether spine or synaptic abnormality is observed in $15 \mathrm{q}$ duplication mice or other models.

\section{Autistic-like behavior of $\mathbf{1 5 q}$ duplication mice}

Behavioral analyses are essential for animal models of autism because major phenotypes of ASDs are behavioral abnormalities and the diagnosis is made by three major phenotypes: impairment in social interaction, impaired social communication, restricted interest and behavior, or resistance to change. Mouse behavioral tests corresponding to human autistic phenotypes have been reported (Moy and Nadler 2008; Silverman et al. 2010). The systematic behavioral analyses were performed for $15 \mathrm{q}$ duplication mice (Nakatani et al. 2009). First, in the three-chamber test for social interaction, WT mice display more time spent near a novel mouse than an empty cage, while no difference of time spent around the novel mouse and the empty cage is observed in patDp/ + mice. In comparison with time between an inanimate object and an empty cage, both patDp/+ and WT mice spend more time near the object than empty cage, indicating that $\mathrm{patDp} /+$ mice are able to see the object. Interestingly, WT mice spend more time around a novel mouse compared with an inanimate object, whereas there was no difference in time spent between the novel mouse and the inanimate object in patDp/+ mice. On the other hand, there was no significant difference between matDp/+ and WT mice in the three-chamber test. These results indicate that patDp/+ mice exhibit impaired social interaction. Similarly, Gabrb3-/- mice spend less time in the proximity of unfamiliar mice than do their control counterparts in a similar social behavior test, although some aspects of social curiosity appear to remain intact (DeLorey et al. 2008).

Second, patDp/+, but not matDp/+, mice display abnormal ultrasonic vocalizations (USVs) (Nakatani et al. 2009). When the pups are separated from their dams, they produce USVs. In WT pups, the numbers of USVs reach a peak around postnatal day five (P5) and then gradually decrease until P14, when their eyes are open and they can communicate through the visual pathway. In contrast, the numbers of USVs remain high at P7 or even at P14 in patDp/+ mice, suggesting that the developmental course of USVs in patDp/+ mice is delayed compared with WT. These results demonstrate that patDp/+ mice may be developmentally abnormal in comparison with WT, although the larger number of USVs in patDp/+ pups may reflect higher anxiety and fear in response to isolation stress. No difference of USVs between matDp/+ and WT mice was observed. The increased USVs were also observed in mice with a maternal deletion from Ube3a to Gabrb3 (Jiang et al. 2010).

Third, ritualistic behavioral inflexibility seen in autistic patients is examined by reversal tasks using learning mazes. In the Barnes maze, WT, patDp/+, and matDp/+ mice exhibit intact spatial learning and memory. In a reversal test, in which the target is altered to the opposite position, WT and matDp/+ mice learn the new target position, whereas $\mathrm{patDp} /+$ mice return to the original position more often than WT and $\mathrm{matDp} /+$ mice, indicating that patDp/+ mice display resistance to change or perseveration (Nakatani et al. 2009). patDp/+ mice also show similar behavior in the Morris water maze. These results suggest that patDp/+ mice exhibit behavioral inflexibility.

In addition to these phenotypes, patDp/+ mice display novelty-induced anxiety and decreased exploratory activity (Tamada et al. 2010). Interestingly, anxiety is also observed in paternal duplication of 15q11-q13 in humans (Mao et al. 2000; Veltman et al. 2005). Mice with maternal deficiency for just the Ube3a gene also show decreased exploratory behavior (Allensworth et al. 2011). In several tests involving food deprivation, such as the novelty suppressed test, radial maze, and Y-maze, patDp $/+$ mice display peculiar behavior (Tamada et al. 2010). Even though patDp/+ mice must be hungry after food deprivation, they do not rush to feed and take more time to proceed to feed than WT mice, and finally perform some tasks that are equivalent to the WT. This behavior is likely to reflect a lack of desire. patDp/+ mice also show less marble burying behavior (Tamada et al. 2010), a method commonly used to assess obsessive-compulsive behavior, which is also seen in Gabrb3 KO mice (Hashemi et al. 2007).

\section{Abnormal serotonin in $\mathbf{1 5 q}$ duplication mice}

The mouse model for 15q duplication can be considered an artificial founder mouse to unravel which gene and/or region in $15 \mathrm{q} 11-\mathrm{q} 13$ is critical for autistic phenotypes. A series of bacterial artificial chromosome (BAC), yeast artificial chromosome (YAC), or other engineered mice with longer insertions that cover the duplicated region will provide useful materials for further investigation. Alternatively, genetic rescue experiments crossed with a series of knockout or deficient mice will be required to identify the gene.

The primary benefit of the mouse model is that it allows us to study abnormality at the molecular and cellular levels. Major behavioral phenotypes appear in patDp/+ mice but not in matDp/+ mice (Nakatani et al. 2009); therefore, genes in the maternally imprinted region can be regarded as candidates for abnormal behaviors observed in patDp/ + mice. Among them, MBII-52, a mouse brain specific 
snoRNA 52 in a huge cluster of non-coding RNAs, would be an interesting candidate for the following reasons. First, MBII-52 is a paternally expressed gene. Second, HBII-52, a human homolog of $M B I I-52$, is reported to be involved in posttranscriptional modification of the serotonin $2 \mathrm{c}$ receptor (5-HT2cR) (Kishore and Stamm 2006). Third, serotonin (5-HT) is well known to be related to the pathophysiology of autistic phenotypes (Whitaker-Azmitia 2005). Fourth, 5 -HT2cR is the only G-protein coupled receptor that undergoes A to I RNA editing, resulting in an amino acid substitution in the second loop of the cytoplasmic domains (Seeburg 2002), which may affect G-protein coupling efficiency. MBII-52 RNA displays an approximately twofold increase in expression in the patDp/ + mice brain compared with matDp/+ and WT mice (Nakatani et al. 2009). Pyrosequencing analyses revealed that the RNA editing ratio in potential editing sites of $5-\mathrm{HT} 2 \mathrm{cR}$ in patDp/+ mice was higher than that in matDp/+ or WT mice. This suggests that increased snoRNA in the patDp/+ brains may affect the RNA editing of 5-HT2cR. Furthermore, a specific agonist for 5-HT2cR induces higher intracellular $\mathrm{Ca}^{2+}$ concentration in primary cultured neurons derived from patDp/+ mice compared with matDp/+ and WT neurons, indicating that serotonergic signals in patDp/+ neurons are different from matDp/+ and WT neurons. This result suggests that alterations in RNA editing of 5 -HT2cR may affect serotonergic signals in neurons and that this alteration in serotonergic signals in patDp/+ neurons may recapitulate abnormal behavior in patDp/+ mice.

Neurochemical analyses revealed abnormal levels of 5HT and its metabolites in the adult cerebellum and midbrain of the duplication mouse. Interestingly, 5-HT in patDp/+ mice was also observed to decrease in all brain regions tested during postnatal weeks 1-3 (Tamada et al. 2010). These results suggest that abnormal 5-HT levels during developmental stages affect development of neurons and neural circuits, and may recapitulate the abnormal behavior seen in patDp/+ mice. Interestingly, the mean 5-HT concentrations are larger in $N d n \mathrm{KO}$ mice than in WT, and the morphologies of 5-HT fibers are altered (Zanella et al. 2008). Combined with these findings, $N d n$ in the region may be involved in the metabolism and development of 5HT. $N d n$ facilitates TrkA signaling for sensory neuron survival (Kuwako et al. 2005). The molecular mechanisms by which $N d n$ might affect 5 -HT metabolism and development remain unknown.

\section{Phenotypes (in)dependent on copy variants}

Mice with a $15 q$ duplication and other genetically engineered mice for genes in 15q11-q13 share some phenotypes, such as obesity, social behavior, and 5-HT concentration. Serotonin concentration seems to correlate with gene dosage of $N d n$ (Tamada et al. 2010; Zanella et al. 2008); however, complex phenotypes such as metabolism, weight control, or social behavior are unlikely to be dependent on simple gene dosage or copy number variants, but above a certain critical threshold, increases or decrease of gene expression may produce the abnormal pathway of these phenotypes.

The idea that phenotypes are dependent on copy variants may not be correct and their underlying mechanisms are unlikely to be simple in humans. In contrast to the interstitial duplication of human chromosome $15 \mathrm{q}$, termed idic (15) syndrome individuals, the presence of a supernumerary marker chromosome formed by the inverted duplication of proximal chromosome 15 , resulting in partial tetrasomy $15 \mathrm{q}$, often display increased, yet inappropriate, social behaviors (Battaglia et al. 2010).

\section{A gap between the mouse model and the human patient}

The mouse model for $15 \mathrm{q}$ duplication as an animal model for human neuropsychiatric disease fulfills construct validity, in which it possesses the same chromosomal abnormality as human patients. Thus, the model can be regarded as a humanoid mouse model for autism in one aspect (Takumi 2010). In terms of humanized models, Tabuchi et al. report a KI mouse for an NLGN3 R541C mutant (Tabuchi et al. 2007). However, the same KI mouse independently generated by Dr. Heintz's group displays no significant or mild social abnormality (Chadman et al. 2008). Further humanized model mice with rare mutations of other molecules, such as serotonin transporter G56A KI mice (Veenstra-Vanderweele et al. 2009), will be expected to display the phenotypes seen in humans.

The allele-specific phenotypes that appeared in $15 \mathrm{q}$ model mice will imply some biological significance that can provide a general concept. However, it is surprising that patDp/+ mice, but not matDp/+ mice, display abnormal social behavior (Nakatani et al. 2009) because maternally duplicated cases in humans are likely to result in an ASD phenotype, while paternal duplications do not (Cook et al. 1997). Although allele-specific methylation seems to be conserved, at least around the IC, in mice with a duplication, the possibility that the imprinting status in other regions is different between human and mouse is not excluded. The timing and mechanism of the expression of the downstream non-coding Snurf-Snrpn exons seem to be different between human and mouse (Chamberlain et al. 2010). Recent systematic analyses of the mouse epigenome reveal that Ube $3 a$ and a GABA receptor subunit are differentially imprinted in different brain areas (Gregg et al. 2010). Alternatively, epigenetic status other than DNA methylation may be different in mice from that in humans. Quantitative 
analysis of GABRB3 transcripts in PWS and AS brain samples show evidence for a paternal expression bias when a biparental 15q11-q13 contribution is lacking (Hogart et al. 2007). The Ube3a-ATS is thought to regulate expression by turning off Ube3a on the paternal allele. This may cause difference between maternal and paternal duplication animals as well and should be investigated. At the very least, there is a significant variability and diversity of clinical phenotypes and gene expression in human chromosome 15q11-q13 duplication syndrome (Hogart et al. 2009; Piard et al. 2010). Further detailed epigenetic analyses both in humans and mice will provide an insight into the imprinting mechanisms.

Acknowledgments The author acknowledges all members of the Takumi laboratory, especially Jin Nakatani for his persistent efforts in providing a useful mouse model, and thanks Kota Tamada for his preparation of the figure and table.

\section{References}

Abrahams BS, Geschwind DH. Advances in autism genetics: on the threshold of a new neurobiology. Nat Rev Genet. 2008;9:341-55.

Allensworth M, Saha A, Reiter LT, Heck DH. Normal social seeking behavior, hypoactivity and reduced exploratory range in a mouse model of Angelman syndrome. BMC Genet. 2011;12:7.

Battaglia A, Parrini B, Tancredi R. The behavioral phenotype of the idic(15) syndrome. Am J Med Genet C Semin Med Genet. 2010;154C:448-55.

Bekker-Jensen S, Rendtlew Danielsen J, Fugger K, Gromova I, Nerstedt A, Lukas C, et al. HERC2 coordinates ubiquitindependent assembly of DNA repair factors on damaged chromosomes. Nat Cell Biol. 2010;12:80-6. sup pp 1-12.

Berkel S, Marshall CR, Weiss B, Howe J, Roeth R, Moog U, et al. Mutations in the SHANK2 synaptic scaffolding gene in autism spectrum disorder and mental retardation. Nat Genet. 2010;42:48991.

Betancur C, Sakurai T, Buxbaum JD. The emerging role of synaptic cell-adhesion pathways in the pathogenesis of autism spectrum disorders. Trends Neurosci. 2009;32:402-12.

Bielinska B, Blaydes SM, Buiting K, Yang T, Krajewska-Walasek M, Horsthemke B, et al. De novo deletions of SNRPN exon 1 in early human and mouse embryos result in a paternal to maternal imprint switch. Nat Genet. 2000;25:74-8.

Bischof JM, Stewart CL, Wevrick R. Inactivation of the mouse Magel2 gene results in growth abnormalities similar to PraderWilli syndrome. Hum Mol Genet. 2007;16:2713-9.

Bolton PF, Dennis NR, Browne CE, Thomas NS, Veltman MW, Thompson RJ, et al. The phenotypic manifestations of interstitial duplications of proximal $15 \mathrm{q}$ with special reference to the autistic spectrum disorders. Am J Med Genet. 2001;105:675-85.

Bolton PF, Veltman MW, Weisblatt E, Holmes JR, Thomas NS, Youings SA, et al. Chromosome 15q11-13 abnormalities and other medical conditions in individuals with autism spectrum disorders. Psychiatr Genet. 2004;14:131-7.

Bourgeron T. A synaptic trek to autism. Curr Opin Neurobiol. 2009;19:231-4.

Bozdagi O, Sakurai T, Papapetrou D, Wang X, Dickstein DL, Takahashi N, et al. Haploinsufficiency of the autism-associated Shank3 gene leads to deficits in synaptic function, social interaction, and social communication. Mol Autism. 2010;1:15.
Bressler J, Tsai TF, Wu MY, Tsai SF, Ramirez MA, Armstrong D, et al. The SNRPN promoter is not required for genomic imprinting of the Prader-Willi/Angelman domain in mice. Nat Genet. 2001;28:232-40.

Browne CE, Dennis NR, Maher E, Long FL, Nicholson JC, Sillibourne $\mathrm{J}$, et al. Inherited interstitial duplications of proximal 15q: genotype-phenotype correlations. Am J Hum Genet. 1997;61:1342-52.

Cassidy SB, Driscoll DJ. Prader-Willi syndrome. Eur J Hum Genet. 2009;17:3-13.

Chadman KK, Gong S, Scattoni ML, Boltuck SE, Gandhy SU, Heintz $\mathrm{N}$, et al. Minimal aberrant behavioral phenotypes of neuroligin-3 R451C knockin mice. Autism Res. 2008;1:147-58.

Chai JH, Locke DP, Greally JM, Knoll JH, Ohta T, Dunai J, et al. Identification of four highly conserved genes between breakpoint hotspots BP1 and BP2 of the Prader-Willi/Angelman syndromes deletion region that have undergone evolutionary transposition mediated by flanking duplicons. Am J Hum Genet. 2003;73:898925.

Chamberlain SJ, Lalande M. Angelman syndrome, a genomic imprinting disorder of the brain. J Neurosci. 2010a;30:995863.

Chamberlain SJ, Lalande M. Neurodevelopmental disorders involving genomic imprinting at human chromosome 15q11-q13. Neurobiol Dis. 2010b;39:13-20.

Chamberlain SJ, Chen PF, Ng KY, Bourgois-Rocha F, Lemtiri-Chlieh F, Levine ES, et al. Induced pluripotent stem cell models of the genomic imprinting disorders Angelman and Prader-Willi syndromes. Proc Natl Acad Sci USA. 2010;107:17668-73.

Cheng VY, Martin LJ, Elliott EM, Kim JH, Mount HT, Taverna FA, et al. Alpha5GABAA receptors mediate the amnestic but not sedative-hypnotic effects of the general anesthetic etomidate. J Neurosci. 2006;26:3713-20.

Colas D, Wagstaff J, Fort P, Salvert D, Sarda N. Sleep disturbances in Ube3a maternal-deficient mice modeling Angelman syndrome. Neurobiol Dis. 2005;20:471-8.

Collinson N, Kuenzi FM, Jarolimek W, Maubach KA, Cothliff R, Sur $\mathrm{C}$, et al. Enhanced learning and memory and altered GABAergic synaptic transmission in mice lacking the alpha 5 subunit of the GABAA receptor. J Neurosci. 2002;22:5572-80.

Cook Jr EH, Scherer SW. Copy-number variations associated with neuropsychiatric conditions. Nature. 2008;455:919-23.

Cook Jr EH, Lindgren V, Leventhal BL, Courchesne R, Lincoln A, Shulman C, et al. Autism or atypical autism in maternally but not paternally derived proximal 15q duplication. Am J Hum Genet. 1997;60:928-34.

Crestani F, Keist R, Fritschy JM, Benke D, Vogt K, Prut L, et al. Trace fear conditioning involves hippocampal alpha5 GABA(A) receptors. Proc Natl Acad Sci USA. 2002;99:8980-5.

Delahanty RJ, Kang JQ, Brune CW, Kistner EO, Courchesne E, Cox NJ, et al. Maternal transmission of a rare GABRB3 signal peptide variant is associated with autism. Mol Psychiatry. 2010;16:86-96.

DeLorey TM, Handforth A, Anagnostaras SG, Homanics GE, Minassian BA, Asatourian A, et al. Mice lacking the beta3 subunit of the GABAA receptor have the epilepsy phenotype and many of the behavioral characteristics of Angelman syndrome. $\mathrm{J}$ Neurosci. 1998;18:8505-14.

DeLorey TM, Sahbaie P, Hashemi E, Homanics GE, Clark JD. Gabrb3 gene deficient mice exhibit impaired social and exploratory behaviors, deficits in non-selective attention and hypoplasia of cerebellar vermal lobules: a potential model of autism spectrum disorder. Behav Brain Res. 2008;187:207-20.

Depienne C, Moreno-De-Luca D, Heron D, Bouteiller D, Gennetier A, Delorme $\mathrm{R}$, et al. Screening for genomic rearrangements and methylation abnormalities of the $15 \mathrm{q} 11-\mathrm{q} 13$ region in autism spectrum disorders. Biol Psychiatry. 2009;66:349-59. 
Dhar MS, Sommardahl CS, Kirkland T, Nelson S, Donnell R, Johnson DK, et al. Mice heterozygous for Atp10c, a putative amphipath, represent a novel model of obesity and type 2 diabetes. J Nutr. 2004; 134:799-805.

Dindot SV, Antalffy BA, Bhattacharjee MB, Beaudet AL. The Angelman syndrome ubiquitin ligase localizes to the synapse and nucleus, and maternal deficiency results in abnormal dendritic spine morphology. Hum Mol Genet. 2008;17:111-8.

Ding F, Prints Y, Dhar MS, Johnson DK, Garnacho-Montero C, Nicholls RD, et al. Lack of Pwcr1/MBII-85 snoRNA is critical for neonatal lethality in Prader-Willi syndrome mouse models. Mamm Genome. 2005;16:424-31.

Ding F, Li HH, Zhang S, Solomon NM, Camper SA, Cohen P, et al. SnoRNA Snord116 (Pwcr1/MBII-85) deletion causes growth deficiency and hyperphagia in mice. PLoS One. 2008;3:e1709.

Doe CM, Relkovic D, Garfield AS, Dalley JW, Theobald DE, Humby $\mathrm{T}$, et al. Loss of the imprinted snoRNA mbii-52 leads to increased $5 \mathrm{htr} 2 \mathrm{c}$ pre-RNA editing and altered 5HT2CR-mediated behaviour. Hum Mol Genet. 2009;18:2140-8.

Doornbos M, Sikkema-Raddatz B, Ruijvenkamp CA, Dijkhuizen T, Bijlsma EK, Gijsbers AC, et al. Nine patients with a microdeletion 15q11.2 between breakpoints 1 and 2 of the Prader-Willi critical region, possibly associated with behavioural disturbances. Eur J Med Genet. 2009;52:108-15.

DuBose AJ, Johnstone KA, Smith EY, Hallett RA, Resnick JL. Atp10a, a gene adjacent to the PWS/AS gene cluster, is not imprinted in mouse and is insensitive to the PWS-IC. Neurogenetics. 2010;11:145-51.

Duker AL, Ballif BC, Bawle EV, Person RE, Mahadevan S, Alliman $\mathrm{S}$, et al. Paternally inherited microdeletion at $15 \mathrm{q} 11.2$ confirms a significant role for the SNORD116 C/D box snoRNA cluster in Prader-Willi syndrome. Eur J Hum Genet. 2010;18:1196-201.

Ferguson C, Hardy SL, Werner DF, Hileman SM, Delorey TM, Homanics GE. New insight into the role of the beta3 subunit of the GABAA-R in development, behavior, body weight regulation, and anesthesia revealed by conditional gene knockout. BMC Neurosci. 2007;8:85.

Gardner JM, Nakatsu Y, Gondo Y, Lee S, Lyon MF, King RA, et al. The mouse pink-eyed dilution gene: association with human Prader-Willi and Angelman syndromes. Science. 1992;257: $1121-4$.

Gerard M, Hernandez L, Wevrick R, Stewart CL. Disruption of the mouse necdin gene results in early post-natal lethality. Nat Genet. 1999;23:199-202

Gillberg C, Steffenburg S, Wahlstrom J, Gillberg IC, Sjostedt A, Martinsson T, et al. Autism associated with marker chromosome. J Am Acad Child Adolesc Psychiatry. 1991;30:489-94.

Glessner JT, Wang K, Cai G, Korvatska O, Kim CE, Wood S, et al. Autism genome-wide copy number variation reveals ubiquitin and neuronal genes. Nature. 2009;459:569-73.

Greer PL, Hanayama R, Bloodgood BL, Mardinly AR, Lipton DM, Flavell SW, et al. The Angelman Syndrome protein Ube3A regulates synapse development by ubiquitinating arc. Cell. 2010;140:704-16

Gregg C, Zhang J, Weissbourd B, Luo S, Schroth GP, Haig D, et al. High-resolution analysis of parent-of-origin allelic expression in the mouse brain. Science. 2010;329:643-8.

Hashemi E, Sahbaie P, Davies MF, Clark JD, DeLorey TM. Gabrb3 gene deficient mice exhibit increased risk assessment behavior, hypotonia and expansion of the plexus of locus coeruleus dendrites. Brain Res. 2007;1129:191-9.

Hauser J, Rudolph U, Keist R, Mohler H, Feldon J, Yee BK. Hippocampal alpha5 subunit-containing GABAA receptors modulate the expression of prepulse inhibition. Mol Psychiatry. 2005; 10:201-7.
Heck DH, Zhao Y, Roy S, LeDoux MS, Reiter LT. Analysis of cerebellar function in Ube3a-deficient mice reveals novel genotype-specific behaviors. Hum Mol Genet. 2008;17:2181-9.

Hogart A, Nagarajan RP, Patzel KA, Yasui DH, Lasalle JM. 15q11-13 GABAA receptor genes are normally biallelically expressed in brain yet are subject to epigenetic dysregulation in autismspectrum disorders. Hum Mol Genet. 2007;16:691-703.

Hogart A, Leung KN, Wang NJ, Wu DJ, Driscoll J, Vallero RO, et al. Chromosome 15q11-13 duplication syndrome brain reveals epigenetic alterations in gene expression not predicted from copy number. J Med Genet. 2009;46:86-93.

Hogart A, Wu D, LaSalle JM, Schanen NC. The comorbidity of autism with the genomic disorders of chromosome 15q11.2-q13. Neurobiol Dis. 2010;38:181-91.

Homanics GE, DeLorey TM, Firestone LL, Quinlan JJ, Handforth A, Harrison NL, et al. Mice devoid of gamma-aminobutyrate type A receptor beta3 subunit have epilepsy, cleft palate, and hypersensitive behavior. Proc Natl Acad Sci USA. 1997;94:4143-8.

Insel TR. The challenge of translation in social neuroscience: a review of oxytocin, vasopressin, and affiliative behavior. Neuron. 2010;65:768-79.

Jiang YH, Armstrong D, Albrecht U, Atkins CM, Noebels JL, Eichele $\mathrm{G}$, et al. Mutation of the Angelman ubiquitin ligase in mice causes increased cytoplasmic p53 and deficits of contextual learning and long-term potentiation. Neuron. 1998;21:799-811.

Jiang YH, Pan Y, Zhu L, Landa L, Yoo J, Spencer C, et al. Altered ultrasonic vocalization and impaired learning and memory in Angelman syndrome mouse model with a large maternal deletion from Ube3a to Gabrb3. PLoS One. 2010;5:e12278.

Johnson DK, Stubbs LJ, Culiat CT, Montgomery CS, Russell LB, Rinchik EM. Molecular analysis of 36 mutations at the mouse pink-eyed dilution (p) locus. Genetics. 1995; 141:1563-71.

Johnstone KA, DuBose AJ, Futtner CR, Elmore MD, Brannan CI, Resnick JL. A human imprinting centre demonstrates conserved acquisition but diverged maintenance of imprinting in a mouse model for Angelman syndrome imprinting defects. Hum Mol Genet. 2006;15:393-404.

Jong MT, Gray TA, Ji Y, Glenn CC, Saitoh S, Driscoll DJ, et al. A novel imprinted gene, encoding a RING zinc-finger protein, and overlapping antisense transcript in the Prader-Willi syndrome critical region. Hum Mol Genet. 1999;8:783-93.

Jurd R, Arras M, Lambert S, Drexler B, Siegwart R, Crestani F, et al. General anesthetic actions in vivo strongly attenuated by a point mutation in the GABA(A) receptor beta3 subunit. FASEB J. 2003;17:250-2.

Kayashima T, Ohta T, Niikawa N, Kishino T. On the conflicting reports of imprinting status of mouse ATP10a in the adult brain: strainbackground-dependent imprinting? J Hum Genet. 2003;48:492-3. author reply 494.

Kishino T, Lalande M, Wagstaff J. UBE3A/E6-AP mutations cause Angelman syndrome. Nat Genet. 1997;15:70-3.

Kishore S, Stamm S. The snoRNA HBII-52 regulates alternative splicing of the serotonin receptor 2C. Science. 2006;311:230-2.

Kozlov SV, Bogenpohl JW, Howell MP, Wevrick R, Panda S, Hogenesch JB, et al. The imprinted gene Magel2 regulates normal circadian output. Nat Genet. 2007;39:1266-72.

Kumar RA, KaraMohamed S, Sudi J, Conrad DF, Brune C, Badner JA, et al. Recurrent 16p11.2 microdeletions in autism. Hum Mol Genet. 2008;17:628-38.

Kuwajima T, Hasegawa K, Yoshikawa K. Necdin promotes tangential migration of neocortical interneurons from basal forebrain. $\mathrm{J}$ Neurosci. 2010;30:3709-14.

Kuwako K, Hosokawa A, Nishimura I, Uetsuki T, Yamada M, Nada S, et al. Disruption of the paternal necdin gene diminishes TrkA signaling for sensory neuron survival. J Neurosci. 2005;25:7090-9. 
Lee S, Walker CL, Karten B, Kuny SL, Tennese AA, O’Neill MA, et al. Essential role for the Prader-Willi syndrome protein necdin in axonal outgrowth. Hum Mol Genet. 2005;14:627-37.

Lehman AL, Nakatsu Y, Ching A, Bronson RT, Oakey RJ, KeiperHrynko $\mathrm{N}$, et al. A very large protein with diverse functional motifs is deficient in rjs (runty, jerky, sterile) mice. Proc Natl Acad Sci USA. 1998;95:9436-41.

Levitt P, Campbell DB. The genetic and neurobiologic compass points toward common signaling dysfunctions in autism spectrum disorders. J Clin Invest. 2009;119:747-54.

Mao R, Jalal SM, Snow K, Michels VV, Szabo SM, Babovic-Vuksanovic D. Characteristics of two cases with $\operatorname{dup}(15)(\mathrm{q} 11.2-\mathrm{q} 12)$ : one of maternal and one of paternal origin. Genet Med. 2000;2:131-5.

Margolis SS, Salogiannis J, Lipton DM, Mandel-Brehm C, Wills ZP, Mardinly AR, et al. EphB-mediated degradation of the RhoA GEF Ephexin5 relieves a developmental brake on excitatory synapse formation. Cell. 2010;143:442-55.

Marshall CR, Noor A, Vincent JB, Lionel AC, Feuk L, Skaug J, et al. Structural variation of chromosomes in autism spectrum disorder. Am J Hum Genet. 2008;82:477-88.

Martin LJ, Zurek AA, MacDonald JF, Roder JC, Jackson MF, Orser BA. Alpha5GABAA receptor activity sets the threshold for longterm potentiation and constrains hippocampus-dependent memory. J Neurosci. 2010;30:5269-82.

Maruyama K, Usami M, Aizawa T, Yoshikawa K. A novel brainspecific mRNA encoding nuclear protein (necdin) expressed in neurally differentiated embryonal carcinoma cells. Biochem Biophys Res Commun. 1991;178:291-6.

Matsuura T, Sutcliffe JS, Fang P, Galjaard RJ, Jiang YH, Benton CS, et al. De novo truncating mutations in E6-AP ubiquitin-protein ligase gene (UBE3A) in Angelman syndrome. Nat Genet. 1997; 15:74-7.

Mercer RE, Wevrick R. Loss of magel2, a candidate gene for features of Prader-Willi syndrome, impairs reproductive function in mice. PLoS One. 2009;4:e4291.

Mills AA, Bradley A. From mouse to man: generating megabase chromosome rearrangements. Trends Genet. 2001;17:331-9.

Miura K, Kishino T, Li E, Webber H, Dikkes P, Holmes GL, et al. Neurobehavioral and electroencephalographic abnormalities in Ube3a maternal-deficient mice. Neurobiol Dis. 2002;9:149-59.

Mohandas TK, Park JP, Spellman RA, Filiano JJ, Mamourian AC, Hawk $\mathrm{AB}$, et al. Paternally derived de novo interstitial duplication of proximal $15 \mathrm{q}$ in a patient with developmental delay. Am J Med Genet. 1999;82:294-300.

Moy SS, Nadler JJ. Advances in behavioral genetics: mouse models of autism. Mol Psychiatry. 2008;13:4-26.

Muscatelli F, Abrous DN, Massacrier A, Boccaccio I, Le Moal M, Cau $\mathrm{P}$, et al. Disruption of the mouse Necdin gene results in hypothalamic and behavioral alterations reminiscent of the human Prader-Willi syndrome. Hum Mol Genet. 2000;9:3101-10.

Nakatani J, Tamada K, Hatanaka F, Ise S, Ohta H, Inoue $\mathrm{K}$, et al. Abnormal behavior in a chromosome-engineered mouse model for human 15q11-13 duplication seen in autism. Cell. 2009;137:123546.

Nicholls RD, Knepper JL. Genome organization, function, and imprinting in Prader-Willi and Angelman syndromes. Annu Rev Genomics Hum Genet. 2001;2:153-75.

Nishimura Y, Martin CL, Vazquez-Lopez A, Spence SJ, AlvarezRetuerto AI, Sigman M, et al. Genome-wide expression profiling of lymphoblastoid cell lines distinguishes different forms of autism and reveals shared pathways. Hum Mol Genet. 2007; 16:1682-98.

Peca J, Feliciano C, Ting JT, Wang W, Wells MF, Venkatraman TN, et al. Shank3 mutant mice display autistic-like behaviours and striatal dysfunction. Nature. 2011;472:437-42.
Piard J, Philippe C, Marvier M, Beneteau C, Roth V, Valduga M, et al. Clinical and molecular characterization of a large family with an interstitial 15q11q13 duplication. Am J Med Genet A. 2010;152A:1933-41.

Pinto D, Pagnamenta AT, Klei L, Anney R, Merico D, Regan R, et al. Functional impact of global rare copy number variation in autism spectrum disorders. Nature. 2010;466:368-72.

Repetto GM, White LM, Bader PJ, Johnson D, Knoll JH. Interstitial duplications of chromosome region 15q11q13: clinical and molecular characterization. Am J Med Genet. 1998;79:82-9.

Roberts SE, Dennis NR, Browne CE, Willatt L, Woods G, Cross I, et al. Characterisation of interstitial duplications and triplications of chromosome 15q11-q13. Hum Genet. 2002;110:227-34.

Rubenstein JL, Merzenich MM. Model of autism: increased ratio of excitation/inhibition in key neural systems. Genes Brain Behav. 2003;2:255-67.

Sahoo T, Peters SU, Madduri NS, Glaze DG, German JR, Bird LM, et al. Microarray based comparative genomic hybridization testing in deletion bearing patients with Angelman syndrome: genotypephenotype correlations. J Med Genet. 2006;43:512-6.

Sahoo T, del Gaudio D, German JR, Shinawi M, Peters SU, Person RE, et al. Prader-Willi phenotype caused by paternal deficiency for the HBII-85C/D box small nucleolar RNA cluster. Nat Genet. 2008;40:719-21.

Sato M, Stryker MP. Genomic imprinting of experience-dependent cortical plasticity by the ubiquitin ligase gene Ube3a. Proc Natl Acad Sci USA. 2010;107:5611-6.

Schaller F, Watrin F, Sturny R, Massacrier A, Szepetowski P, Muscatelli F. A single postnatal injection of oxytocin rescues the lethal feeding behaviour in mouse newborns deficient for the imprinted Magel2 gene. Hum Mol Genet. 2010;19:4895-905.

Schanen NC. Epigenetics of autism spectrum disorders. Hum Mol Genet. 2006;15(Spec No 2):R138-50.

Schenck A, Bardoni B, Moro A, Bagni C, Mandel JL. A highly conserved protein family interacting with the fragile $\mathrm{X}$ mental retardation protein (FMRP) and displaying selective interactions with FMRP-related proteins FXR1P and FXR2P. Proc Natl Acad Sci USA. 2001;98:8844-9.

Seeburg PH. A-to-I editing: new and old sites, functions and speculations. Neuron. 2002;35:17-20.

Silverman JL, Yang M, Lord C, Crawley JN. Behavioural phenotyping assays for mouse models of autism. Nat Rev Neurosci. 2010;11:490 502.

Skryabin BV, Gubar LV, Seeger B, Pfeiffer J, Handel S, Robeck T, et al. Deletion of the MBII-85 snoRNA gene cluster in mice results in postnatal growth retardation. PLoS Genet. 2007;3:e235.

Sutcliffe JS, Nurmi EL. Genetics of childhood disorders: XLVII. Autism, part 6: duplication and inherited susceptibility of chromosome 15q11-q13 genes in autism. J Am Acad Child Adolesc Psychiatry. 2003;42:253-6.

Tabuchi K, Blundell J, Etherton MR, Hammer RE, Liu X, Powell CM, et al. A neuroligin-3 mutation implicated in autism increases inhibitory synaptic transmission in mice. Science. 2007;318:71-6.

Takumi T. A humanoid mouse model of autism. Brain Dev. 2010;32:753-8.

Tam GW, van de Lagemaat LN, Redon R, Strathdee KE, Croning MD, Malloy MP, et al. Confirmed rare copy number variants implicate novel genes in schizophrenia. Biochem Soc Trans. 2010;38:445-51.

Tamada K, Tomonaga S, Hatanaka F, Nakai N, Takao K, Miyakawa T, et al. Decreased exploratory activity in a mouse model of $15 \mathrm{q}$ duplication syndrome; implications for disturbance of serotonin signaling. PLoS One. 2010;5:e15126.

Toro R, Konyukh M, Delorme R, Leblond C, Chaste P, Fauchereau F, et al. Key role for gene dosage and synaptic homeostasis in autism spectrum disorders. Trends Genet. 2010;26:363-72. 
Tsai TF, Armstrong D, Beaudet AL. Necdin-deficient mice do not show lethality or the obesity and infertility of Prader-Willi syndrome. Nat Genet. 1999a;22:15-6.

Tsai TF, Jiang YH, Bressler J, Armstrong D, Beaudet AL. Paternal deletion from Snrpn to Ube3a in the mouse causes hypotonia, growth retardation and partial lethality and provides evidence for a gene contributing to Prader-Willi syndrome. Hum Mol Genet. 1999b;8:1357-64.

Ugarte SD, Homanics GE, Hammond DL. Effect of embryonic knockdown of GABAA receptors on the levels of monoamines and their metabolites in the CNS of the mouse. Brain Res. 2001;904:290-7.

Van Buggenhout G, Fryns JP. Angelman syndrome (AS, MIM 105830). Eur J Hum Genet. 2009;17:1367-73.

van der Weyden L, Bradley A. Mouse chromosome engineering for modeling human disease. Annu Rev Genomics Hum Genet. 2006;7:247-76.

van der Zwaag B, Staal WG, Hochstenbach R, Poot M, Spierenburg HA, de Jonge MV, et al. A co-segregating microduplication of chromosome 15q11.2 pinpoints two risk genes for autism spectrum disorder. Am J Med Genet B Neuropsychiatr Genet. 2010;153B:960-6.

van Woerden GM, Harris KD, Hojjati MR, Gustin RM, Qiu S, de Avila Freire R, et al. Rescue of neurological deficits in a mouse model for Angelman syndrome by reduction of alphaCaMKII inhibitory phosphorylation. Nat Neurosci. 2007;10:280-2.

Veenstra-Vanderweele J, Jessen TN, Thompson BJ, Carter M, Prasad $\mathrm{HC}$, Steiner JA, et al. Modeling rare gene variation to gain insight into the oldest biomarker in autism: construction of the serotonin transporter Gly56Ala knock-in mouse. J Neurodev Disord. 2009;1:158-71.

Veltman MW, Thompson RJ, Craig EE, Dennis NR, Roberts SE, Moore V, et al. A paternally inherited duplication in the PraderWilli/Angelman syndrome critical region: a case and family study. J Autism Dev Disord. 2005;35:117-27. von der Lippe C, Rustad C, Heimdal K, Rodningen OK. 15q11.2 microdeletion - seven new patients with delayed development and/ or behavioural problems. Eur J Med Genet. 2011;54(3):357-60.

Vorstman JA, Staal WG, van Daalen E, van Engeland H, Hochstenbach PF, Franke L. Identification of novel autism candidate regions through analysis of reported cytogenetic abnormalities associated with autism. Mol Psychiatry. 2006;11(1):18-28.

Walkowicz M, Ji Y, Ren X, Horsthemke B, Russell LB, Johnson D, et al. Molecular characterization of radiation- and chemically induced mutations associated with neuromuscular tremors, runting, juvenile lethality, and sperm defects in jdf2 mice. Mamm Genome. 1999; 10:870-8.

Weiss LA, Shen Y, Korn JM, Arking DE, Miller DT, Fossdal R, et al. Association between microdeletion and microduplication at 16p11.2 and autism. N Engl J Med. 2008;358:667-75.

Whitaker-Azmitia PM. Behavioral and cellular consequences of increasing serotonergic activity during brain development: a role in autism? Int J Dev Neurosci. 2005;23:75-83.

Wisor JP, DeLorey TM, Homanics GE, Edgar DM. Sleep states and sleep electroencephalographic spectral power in mice lacking the beta 3 subunit of the GABA(A) receptor. Brain Res. 2002;955:221-8.

Yang T, Adamson TE, Resnick JL, Leff S, Wevrick R, Francke U, et al. A mouse model for Prader-Willi syndrome imprinting-centre mutations. Nat Genet. 1998;19:25-31.

Yashiro K, Riday TT, Condon KH, Roberts AC, Bernardo DR, Prakash R, et al. Ube3a is required for experience-dependent maturation of the neocortex. Nat Neurosci. 2009;12:777-83.

Yu Y, Bradley A. Engineering chromosomal rearrangements in mice. Nat Rev Genet. 2001;2:780-90.

Zanella S, Watrin F, Mebarek S, Marly F, Roussel M, Gire C, et al. Necdin plays a role in the serotonergic modulation of the mouse respiratory network: implication for Prader-Willi syndrome. J Neurosci. 2008;28:1745-55. 